The two force vectors $q_{1}$ and $q_{2}$, with their direction cosines, $\lambda_{1}, \mu_{1}, \gamma_{1}$, and $\lambda_{2}, \mu_{2}, \gamma_{2}$.

The two intersection curves $r w s_{1}$ and $r w s_{2}$ with the reciprocal wave surface.

The two reciprocal wave fronts $r w f_{1}$ and $r w f_{2}$.

The two reciprocal wave normals or reciprocal velocities, $\omega_{1}^{\prime}, \omega_{2}^{\prime}$, and their direction cosines, $l_{1}^{\prime}, m_{1}^{\prime}, n_{1}^{\prime}$ and $l_{2}^{\prime}, m_{2}^{\prime}, n_{2}^{\prime}$.

The two vectors $r_{1}^{\prime}$ and $r_{2}^{\prime}$ of the reciprocal wave surface and their direction cosines, $l, m, n$.

All the right angles are indicated and the important angle $\delta$, made by the force vector, is showln in one case.

Clearness is given to the diagram by placing the plane normal to the observer's line of sight. The planes $\gamma_{1}, \omega_{1}$ and $\omega_{2}, \gamma_{2}$ are at right as the auxiliary vectors show.

Naturally the above method is even more pertinent to the modern methods of vector analysis. The diagrams, like the computations, gain in simplicity. And yet it is just here that authors are peculiarly unwilling to fix the ideas of the student to a definite case. Demonstrations in themselves admirably lucid become confused in effect, because the reader is all the while drifting in the haze of the absolute generality of the statement of the premises.

Carl Barus

\section{A PRELIMINARY NOTE ON THE CHROMOSOMES OF CENOTHERA LAMARCKIANA AND ONE OF ITS MUTANTS, 0. Gigas}

THE exceptional opportunities offered at this station for a study of inheritance as manifested in the germ cells of the Enotheras led me to undertake a study of the chromosomes of Enothera Lamarckiana, its mutants and hybrids.

The work was begun after the flowering season had passed, however; therefore only somatic cells from the growing root tips of potted plants in the rosette stage have so far been available for study; and it is the purpose of this note, pending the completion of a more general study of the EEnotheras, merely to call attention to a most unexpected contrast found in the number of chromosomes of $O$. $L a$ -

marckiana and one of its mutants, O. gigas, both pure bred.

Because of the smallness of the chromatic figures and the low percentage of figures studied in which the chromosomes could be counted with certainty, I do not at present feel justified in stating the exact number in either form; but I can state unreservedly what is of more interest, that in all the somatic cells of $O$. gigas arising from $O$. Lamarckiana in which the chromosomes could be counted with precision, the number has become approximately double that of the parental form, O. Lamarckiana. This result was unexpected, as a somewhat hasty survey of the tips of

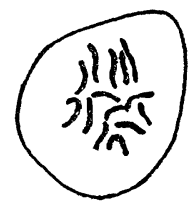

Oenothera Lomarckiana.

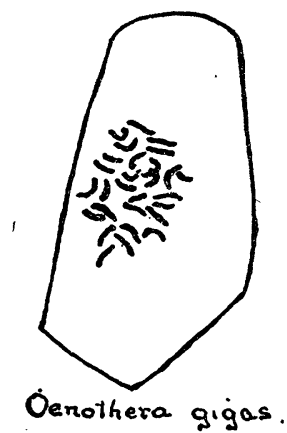

several other mutants previous to the study of gigas had indicated a number closely approaching or identical with that of the parental form. Gates, in his "Preliminary Note on Pollen Development in Enothera lata de Vries and its Hybrids," published in ScIENCE, February 15, 1907, states that in a cross resulting from the pollination of $O$. lata by O. Lamarckiana, "the sporophyte count for the 0 . Lamarckiana side of the cross is at least twenty. The conclusion from this is that pure $O$. Lamarckiana itself must have over twenty chromosomes." In his paper on "Pollen Development in Hybrids of $E_{n o-}$ thera lata $\times 0$. Lamarckiana, and its Relation to Mutation," he adds in a foot-note on page 109: "The inference that $O$. $L a$ marckiana itself has the same number of chromosomes as the dominant $O$. Lamarckiana hybrid is also apparently not borne out by the facts." From my own observations on all

${ }^{1}$ Botanical Gazette, February, 1907. 
pure-bred O. Lamarckiana so far studied I have found no indication of the number ever approaching twenty; but from the evidence of repeated counts it seems to be fourteen or fifteen. I have at least eighteen good clear demonstrations of mitotic figures showing only fourteen chromosomes, all distinctly outlined and clearly defined-with no trace of a chromosome in a preceding or following section; on the other hand, I have encountered a suffcient number of less clearly defined figures, in which there seems to be but thirteen, and in others fifteen chromosomes, to make it necessary to state the number for the present with reserve. Chromosomes frequently lie in such positions as to make it impossible to distinguish between a long-looped form and two so placed as to give a similar appearance; also a looped chromosome may be sectioned at a point to give the two halves the appearance of distinct individuals.

The number of chromosomes characteristic of the somatic cells of $O$. gigas is probably twenty-eight or twenty-nine, although the diffculty in counting is here increased by the large number; however, I have six or seven excellent figures showing twenty-eight sharplydefined chromosomes, and as many more, not so clearly outlined, in which there is a strong indication of twenty-nine. It is hoped that the hundreds of new sections now in process of preparation for study will establish the facts, shortly.

Other points of interest are coming to light, particularly in connection with the hybridization of mutants, and will be mentioned in a later note.

Station for Experimental Evolution, Cold Spring Harbor, L. I., June 28, 1907

\section{CURRENT NOTES ON LAND FORMS}

\section{DIAMOND HEAD AND MOHOKEA}

C. H. Hiтchсоск has recently described a tuff cone and a caldera in the Hawaiian Islands ("Geology of Diamond Head, Oahu," Bull. G. S. A., XVII., 1906, 469-484; "Mohokea Caldera," ibid., 485-496). Diamond Head, on the island of Oahu, is a well- formed tuff cone with a broad and shallow crater, which the author concludes was thrown up explosively from beneath the level of the sea, the volcanic material having been ejected through fossiliferous limestones of Tertiary age. The cone is compared with the Monte Nuovo near Naples. Considerable attention is given the conflicting theory that the cone was built up gradually by the slow accumulation of material ejected at long intervals. The features of the cone are illustrated by several plates.

Mohokea, on the island of Hawaii, is described as a very irregular caldera only partially enclosed, the open side being toward the sea. Two parallel lines of faulted and tilted lava blocks cross the caldera from southeast to northwest, and are believed to be part of the overlying crust which dropped in when the caldera was formed, although the blocks themselves have been in part crowded up until their crests rise higher than the surface without the caldera. Mohokea is compared with the irregular Haleakala caldera, and illustrations of both are given.

D. W. J.

\section{A PENEPLAIN IN EQUATORIAL AFRICA}

IT $_{T}$ is generally accepted among physiographers that a peneplain worn down on crystalline rocks in a humid climate would be heavily cloaked with a deep soil of local weathering; and in favor of this opinion the deeply decayed rocks of the somewhat uplifted and dissected Appalachian Piedmont belt may be instanced. In a subarid climate the case is different.

An excellent account of an extensive peneplain, exposing large areas of bare rock, on the southern border of the French Sahara in latitude $18^{\circ}$ to $21^{\circ} \mathrm{N}$., northeast of the great bend of the Niger and on the arid outer border of the subequatorial (summer) rains, is given by E. F. Gautier ("A travers le Sahara français," La Géogr., XV., 1907, 1-28). The rocks of the region are for the most part Archean granites and gneisses, broken here and there by less ancient igneous intrusions, and associated with belts of strongly folded and 